\title{
Evaluation of Antibiogram, Genotype and Phylogenetic Analysis of Biofield Treated Nocardia otitidis
}

\author{
Mahendra Kumar Trivedi ${ }^{1}$, Alice Branton ${ }^{1}$, Dahryn Trivedi ${ }^{1}$, Gopal Nayak ${ }^{1}$, Sambhu Charan Mondal ${ }^{2}$ and Snehasis Jana ${ }^{2 *}$ \\ ${ }^{1}$ Trivedi Global Inc., 10624 S Eastern Avenue Suite A-969, Henderson, NV 89052, USA \\ ${ }^{2}$ Trivedi Science Research Laboratory Pvt. Ltd., Hall-A, Chinar Mega Mall, Chinar Fortune City, Hoshangabad Rd., Bhopal- 462026, Madhya Pradesh, India
}

\begin{abstract}
Nocardiosis is a soil-borne aerobic infection caused by Nocardia species commonly affects the respiratory tract. Nocardia otitidis (N. otitidis) is the key organism for non-mycobacterial tuberculosis. The current study was attempted to investigate the effect of Mr. Trivedi's biofield energy treatment on $N$. otitidis and analyzed for antimicrobial susceptibility pattern, minimum inhibitory concentration (MIC), DNA polymorphism by Random Amplified Polymorphic DNA (RAPD) and 16S rDNA sequencing. The strain of $N$. otitidis (ATCC 14630) was divided into two parts, control and treated. Antimicrobial susceptibility was studied using the broth microdilution technique. Overall, the MIC values of $16.67 \%$ antimicrobials were changed in the treated group of $N$. otitidis as compared to the control. Moreover, MIC value of trimethoprim/sulfamethoxazole was reduced by two-fold $(0.5 / 9.5$ to $0.25 / 4.75 \mu \mathrm{g} / \mathrm{mL})$ in the biofield energy treated sample as compared to the control without alteration in the sensitivity spectrum. The 16S rDNA analysis showed that the treated sample was detected as Enterobacter aerogenes strain NCTC10006T (GenBank Accession No: AJ251468) with $98 \%$ identity of gene sequencing data. However, the nearest homolog genus-species was found as Kluyvera cryocrescens (GenBank Accession No: AM184245). Using RAPD biomarkers, the sample showed an average range of 34 to $53 \%$ of polymorphism among treated samples as compared to the control. The $16 \mathrm{~S}$ rDNA sequencing of treated sample was carried out to correlate the phylogenetic relationship of $N$. otitidis with other bacterial species. These results suggested that Mr. Trivedi's biofield energy treatment has a significant impact on $N$. otitidis.
\end{abstract}

Keywords: Nocardia otitidis; Nocardiosis; Antimicrobial susceptibility; Biofield energy treatment; $16 \mathrm{~S}$ rDNA sequencing; Random amplified polymorphic DNA

Abbreviations: NIH/NCCAM: National Institute of Health/ National Center for Complementary and Alternative Medicine; ATCC: American Type Culture Collection; MIC: Minimum Inhibitory Concentration; OTUs: Operational Taxonomic Units; NCBI: National Center for Biotechnology Information; MEGA: Molecular Evolutionary Genetics Analysis; PCR: Polymerase Chain Reaction; RDP: Ribosomal Database Project; RAPD: Random Amplified Polymorphic DNA; CNS: Central Nervous System

\section{Introduction}

The genus Nocardia is associated with the group of microorganisms known as the aerobic actinomycetes and belongs to the family of Mycobacteriaceae. Nocardia contains tuberculostearic acids but that differ from the mycobacteria by the possession of short-chain (40 to 60 carbons) mycolic acids [1]. Nocardia otitidis (N. otitidis) is a weak filamentous Gram-positive, catalase-positive, branching rods shaped bacterium that appears similar to Actinomyces species. However, it can usually be differentiated from Actinomyces by acid-fast staining [2]. The taxonomic history of the genus Nocardia is controversial [3]. Nocardia typically exhibits varying degrees of acid fastness due to the presence of cell wall mycolic acid. The genus is typically similar to the genus of Mycobacterium. Mordarska et al. had studied the short-chain fatty acids content in the cell wall of Nocardia and Mycobacterium genera based on gas-liquid chromatography analysis did not find any difference between two genera [4]. Based on immunoblot and enzyme-linked immunosorbent assay (ELISA) techniques that detect specific antibodies that appear as common in various Nocardia and Actinomadura species. These antigens do not react with the antibodies produced in response to Mycobacterium tuberculosis infections [5]. Most of Nocardial infections occur in the United States due to inhalation of airborne spores or mycelial fragments from the environmental sources [6]. The most common manifestation of Nocardial disease is pulmonary nocardiosis [7], extrapulmonary disease [8], and ocular nocardiosis [9] in immunocompromised patients. Infectious Diseases Society of America (IDSA) reported that between 500 and 1,000 cases of Nocardial infections are recognized in the United States each year, of which $85 \%$ are serious pulmonary or systemic infections [10].

Since 1940s, the sulfonamides have been the drugs of choice for the treatment of nocardiosis [11]. Due to high mortality rate (50\%) in patients with central nervous system (CNS) Nocardia infections (Nocardia brain abscess) and patients with non-CNS overwhelming or disseminated disease, the treatment strategy is inadequate. However, the combination of sulfamethoxazole with trimethoprim is often used as the drug of choice for the treatment of nocardiosis [12]. Therefore, some alternative strategies are needed to treat against nocardiosis. Biofield energy has been known as an alternative approach which may be useful as an alternative treatment to Nocardia infected patients. National Institute of Health/National Center for Complementary and Alternative Medicine (NIH/NCCAM) have reported that biofield (putative energy fields) or electromagnetic based energy therapies were commonly used to promote the health and healing [13]. Harold Saxton Burr had performed the detailed studies on the correlation of electric current with the physiological process and concluded that every single process in the human body had an electrical significance [14]. Recently, it was discovered that all the electrical processes happening in the human body have strong relationship with the magnetic field as required by

*Corresponding author: Snehasis Jana, Trivedi Science Research Laboratory Pvt. Ltd., Hall-A, Chinar Mega Mall, Chinar Fortune City, Hoshangabad Rd. Bhopal- 462026, Madhya Pradesh, India, Tel: +91-755-6660006, E-mail: publication@trivedisrl.com

Received August 31, 2015; Accepted September 21, 2015; Published September 29, 2014

Citation: Trivedi MK, Branton A, Trivedi D, Nayak G, Mondal SC, et al. (2015) Evaluation of Antibiogram, Genotype and Phylogenetic Analysis of Biofield Treated Nocardia otitidis. Biol Syst Open Access 4: 143. doi:10.4172/2329-6577.1000143

Copyright: ( 2015 Trivedi MK, et al. This is an open-access article distributed under the terms of the Creative Commons Attribution License, which permits unrestricted use, distribution, and reproduction in any medium, provided the original author and source are credited. 
Ampere's law, which states that the moving charge produces magnetic fields in the surrounding space $[15,16]$. Thus, a human body emits the electromagnetic waves in the form of bio-photons that is also known as ultra-weak photon emissions (UPE). It surrounds the body and it is commonly known as biofield. Therefore, the biofield consists of an electromagnetic field, being generated by moving electrically charged particles (ions, cell, molecule, etc.) inside the human body [17]. The transfer of information from cell to cell or DNA or storage by biophotons has been demonstrated in plants, bacteria, animal neutriophil granulocytes and kidney cells [18]. Prakash et al. in 2015 reported that the various scientific instruments such as Kirlian photography, polycontrast interference photography (PIP) and resonance field imaging (RFI) can be extensively used to measure the biofield of human body [19]. Thus, human has the ability to harness the energy from the environment or universe and can transmit into any living or nonliving object(s) around the Globe. The objects always receive the energy and responding into the useful way that is called biofield energy and the process is known as biofield energy treatment. Mr. Mahendra Trivedi's unique biofield energy treatment (The Trivedi Effect ${ }^{ø}$ ) has been known to improve the overall productivity of crops [20,21], altered characteristics features of microbes [22-24], alter the structural, physical and thermal properties of several metals $[25,26]$, and improved growth and anatomical characteristics of various medicinal plants $[27,28]$.

Based on clinical significance of $N$. otitidis and significant impact of Mr. Trivedi's biofield energy modality on microbes, the present work was undertaken to evaluate the impact of Mr. Trivedi's biofield energy on $N$. otitidis in relation to antimicrobials susceptibility, minimum inhibitory concentration (MIC), random amplified polymorphic DNA analysis (RAPD) and 16S rDNA sequencing.

\section{Materials and Methods}

N. otitidis, American Type Culture Collection (ATCC 14630) strain was procured from Bangalore Genei, Bangalore-India in two vials A and $\mathrm{B}$. Two different sealed packs were stored with proper storage conditions until further use. All the tested antimicrobials were procured from Sigma-Aldrich, India. The antimicrobial susceptibility and MIC were estimated with the help of broth micro dilution technique as per the Clinical Laboratory Standards Institute (CLSI) guidelines document number M24-A [29]. The 16S rDNA sequencing and DNA fingerprinting (RAPD) studies were carried out using Ultrapure Genomic DNA Prep Kit; Cat KT 83 (Bangalore Genei, India).

\section{Experimental design and biofield treatment strategy}

N. otitidis strain was divided into two groups, i.e., control and treated. The treated group was in sealed pack and handed over to $\mathrm{Mr}$. Trivedi for biofield energy treatment under laboratory conditions. $\mathrm{Mr}$. Trivedi provided the treatment through his energy transmission process to the treated group without touching the sample. After treatment, control and treated groups were assessed on day 10 for antimicrobial susceptibility, and MIC. For RAPD analysis three inoculums (one for control and the other two for treated named as treated A and B) were prepared from $N$. otitidis samples. These two biofield treated samples $\mathrm{A}$ and $\mathrm{B}$ were sub-cultured by taking $1 \%$ inoculum and inoculated to fresh $5 \mathrm{ml}$ medium and labeled as treatment A-1 and treatment B-1, respectively. The result of treated sample was compared with respect to the control. The $16 \mathrm{~S}$ rDNA analysis was performed on biofield treated samples A and its subcultured sample A1.

\section{Antimicrobial susceptibility test}

The antimicrobial susceptibility testing is important for clinically significant species. The investigation of antimicrobial susceptibility of $N$. otitidis was carried out with the help of broth micro dilution technique, as per CLSI guidelines. Broth micro dilution was recommended for isolates of rapidly growing mycobacteria (RGM) based on CLSI published guidelines and recommendations for testing of nontuberculous mycobacteria (CLSI, M24-A, 2003) [29]. The detailed experimental procedure and conditions were followed as per the manufacturer's instructions. The antimicrobial susceptibility pattern (S: Susceptible, R: Resistant) and minimum inhibitory concentration (MIC) were determined by observing the lowest antimicrobial concentration showing inhibition of growth.

\section{Random amplified polymorphic DNA (RAPD) analysis}

For DNA fingerprinting (RAPD) analysis all the treated samples (A, A1, B, and B1) were incubated at $37^{\circ} \mathrm{C}$ with $160 \mathrm{rpm}$ for $18 \mathrm{~h}$. Subsequently, the cultures were spun down, pelleted at $5000 \mathrm{rpm}$ at $40^{\circ} \mathrm{C}$ for 10 minutes and the genomic DNA was isolated for control and treated samples using Genomic DNA Prep Kit (Bangalore Genei, India). RAPD was performed with all samples of $N$. otitidis using five RAPD primers, which were labelled as RBA8A, RBA13A, RBA20A, RBA10A and RBA15A were adopted from earlier studies. The PCR mixture contained $2.5 \mu \mathrm{L}$ each of buffer, $4.0 \mathrm{mM}$ each of dNTP, $2.5 \mu \mathrm{M}$ each of primer, $5.0 \mu \mathrm{L}$ (approximately $20 \mathrm{ng}$ ) of each genomic DNA, $2 \mathrm{U}$ each of Taq polymerase, $1.5 \mu \mathrm{L}$ of $\mathrm{MgCl}_{2}$ and $9.5 \mu \mathrm{L}$ of water in a total of $25 \mu \mathrm{L}$ with the following PCR amplification protocol; initial denaturation at $94^{\circ} \mathrm{C}$ for $7 \mathrm{~min}$, followed by 8 cycles of denaturation at $94^{\circ} \mathrm{C}$ for $1 \mathrm{~min}$, annealing at $35^{\circ} \mathrm{C}$ for $1 \mathrm{~min}$, and extension at $72^{\circ} \mathrm{C}$ for 2 min; and 35 cycle of denaturation at $94^{\circ} \mathrm{C}$ for $1 \mathrm{~min}$, annealing at $38^{\circ} \mathrm{C}$ for $1 \mathrm{~min}$, and extension at $72^{\circ} \mathrm{C}$ for $1.5 \mathrm{~min}$; and the final extension at $72^{\circ} \mathrm{C}$ for $7 \mathrm{~min}$. Amplified PCR products from all samples (control and treated) were separated on $1.5 \%$ agarose gels at 75 volts, stained with ethidium bromide and visualized under UV illumination [30]. The percentage of polymorphism was calculated using following equation:

\section{Percent polymorphism $=\mathrm{A} / \mathrm{B} \times 100$}

Where, $\mathrm{A}=$ Number of polymorphic bands in treated sample; and $\mathrm{B}=$ Number of polymorphic bands in control.

\section{Amplification and gene sequencing of $16 \mathrm{~S}$ rDNA}

Genomic DNA was isolated from $N$. otitidis cells (set A, sample coded as $9 \mathrm{~A}$ ) using genomic purification kit, according to the manufacturer instructions. 16S rDNA gene $(\sim 1.5 \mathrm{~kb})$ fragment was amplified with the help of high-fidelity polymerase chain reaction (PCR) using universal primers; forward primer ( $5^{\prime}$-AGAGTTTGATCCTGGCTCAG- $3^{\prime}$ ) and reverse primer ( $3^{\prime}$-ACGGTCATACCTTGTTACGACTT-5'). Amplified products were subjected to gel electrophoresis in $1.0 \%$ agarose gel, stained with ethidium bromide and visualized under UV light in a gel documentation unit (BioRad Laboratories, USA). The PCR amplified fragment was purified from the agarose gel using a DNA gel extraction kit. Sequencing of amplified product was done on a commercial basis from Bangalore Genei, India. The $16 \mathrm{~S}$ rDNA sequences obtained were aligned and compared with the sequences stored in GenBank database available from National Center for Biotechnology Information (NCBI) using the algorithm BLASTn program. Multiple sequence alignment/ phylogenetic tree were established using MEGA3.1 molecular software [31].

\section{Results and Discussion}

\section{Antimicrobial susceptibility test}

Antimicrobial susceptibility pattern of Nocardia can vary from 
species to species. The therapeutic effectiveness depends on the proper identification of species in infected patients and on in vitro sensitivity studies [32]. The antimicrobial sensitivity assay against Nocardia species had been especially considered in refractory cases. A standard test for antimicrobials sensitivity assessed by broth micro dilution and with cation-supplemented Mueller-Hinton broth has been approved by the National Committee for Clinical Laboratory Standards (NCCLS) [29]. The outcome of N. otitidis susceptibility pattern and MIC values of tested antimicrobials after biofield energy treatment are summarized in Table 1 and 2 respectively. The data were analyzed and compared with respect to the control. Study was carried out in twelve antimicrobials for assessment of antimicrobial susceptibility and MIC value. The treated cells of $N$. otitidis did not show any alteration with respect to antimicrobial susceptibility pattern as compared to the control (Table 1). The susceptible nature of $N$. otitidis to amikacin, sulfamethoxazole, and ciprofloxacin and resistance pattern to ceftriaxone, amoxicillinclavulanic acid, and imipenem were well corroborated with the literature data [3]. Beside this, the MIC value of trimethoprim/ sulfamethoxazole was reduced by two-fold $(0.5 / 9.5$ to $0.25 / 4.75 \mu \mathrm{g} / \mathrm{mL})$ in biofield energy treated sample as compared to the control sample. Moreover, the MIC value was slightly reduced ( $>32 / 16$ to $32 / 16 \mu \mathrm{g} / \mathrm{mL})$ in amoxicillin/k-clavulanate after the biofield therapy. Overall, $16.67 \%$

\begin{tabular}{|c|l|c|c|}
\hline S. No. & Antimicrobial & Control & Treatment \\
\hline 1. & Linezolid & $\mathrm{S}$ & $\mathrm{S}$ \\
\hline 2. & Clarithromycin & $\mathrm{R}$ & $\mathrm{R}$ \\
\hline 3. & Amikacin & $\mathrm{S}$ & $\mathrm{S}$ \\
\hline 4. & Cefoxitin & $\mathrm{R}$ & $\mathrm{R}$ \\
\hline 5. & Ceftriaxone & $\mathrm{R}$ & $\mathrm{R}$ \\
\hline 6. & Imipenem & $\mathrm{S}$ & $\mathrm{R}$ \\
\hline 7. & Minocycline & $\mathrm{S}$ & $\mathrm{S}$ \\
\hline 8. & Tobramycin & $\mathrm{S}$ & $\mathrm{S}$ \\
\hline 9. & Ciprofloxacin & $\mathrm{S}$ & $\mathrm{S}$ \\
\hline 10. & Gatifloxacin & $\mathrm{R}$ & $\mathrm{S}$ \\
\hline 11. & Amoxicillin/k-clavulanate & $\mathrm{S}$ & $\mathrm{R}$ \\
\hline 12. & Trimethoprim/sulfamethoxazole & $\mathrm{S}$ \\
\hline
\end{tabular}

R: Resistant; S: Susceptible; Control: ATCC strain of $N$. otitidis (without biofield energy treatment); Treatment: ATCC strain of $N$. otitidis (with Mr. Trivedi's biofield energy treatment)

Table 1: Antimicrobial susceptibility pattern of antimicrobials against ATCC strain of Nocardia otitidis after biofield treatment on day 10 as per CLSI guidelines.

\begin{tabular}{|c|l|c|c|}
\hline S. No. & Antimicrobial & Control & Treatment \\
\hline 1. & Linezolid & 2.0 & 2.0 \\
\hline 2. & Clarithromycin & $>32.0$ & $>32.0$ \\
\hline 3. & Amikacin & $<1.0$ & $<1.0$ \\
\hline 4. & Cefoxitin & 256.0 & 256.0 \\
\hline 5. & Ceftriaxone & 64.0 & 64.0 \\
\hline 6. & Imipenem & 64.0 & 64.0 \\
\hline 7. & Minocycline & 1.0 & 1.0 \\
\hline 8. & Tobramycin & 4.0 & 8.0 \\
\hline 9. & Ciprofloxacin & 0.12 & 4.0 \\
\hline 10. & Gatifloxacin & $>32 / 16$ & 0.12 \\
\hline 11. & Amoxicillin/k-clavulanate & $0.5 / 9.5$ & $0.25 / 4.75$ \\
\hline 12. & Trimethoprim/sulfamethoxazole & & \\
\hline
\end{tabular}

CLSI: Clinical and Laboratory Standards Institute; MIC values are presented as $\mu \mathrm{g} / \mathrm{mL}$; Control: ATCC strain of $N$. otitidis (without biofield energy treatment); Treatment: ATCC strain of $N$. otitidis (with Mr. Trivedi's biofield energy treatment)

Table 2: Minimum inhibitory concentration (MIC) of antimicrobials against ATCC strain of Nocardia otitidis after biofield energy treatment on day 10 as per CLSI guidelines. out of twelve antimicrobials showed an alteration of MIC values. Rest of the antimicrobials did not show any alteration of MIC values with respect to the control sample. Based on the literature, a combination of sulfa and antimalarial drugs, i.e., trimethoprim/sulfamethoxazole are the drug of choice against Nocardia infections as compared to the single sulfa drug $[11,12]$. In this experiment, the susceptibility nature of trimethoprim/sulfamethoxazole was constant in both controls as well as in treated sample, while the MIC value was reduced by twofold in treated sample after Mr. Trivedi's biofield energy treatment. Hence, authors assumed that this improvement of MIC value without alteration of sensitivity pattern may be due to the effect of putative energy transmit through biofield healing (Table 2).

\section{Random amplified polymorphic DNA (RAPD) analysis}

The treated and control samples were identified on the basis of their different and discriminative RAPD patterns. RAPD is a preferred tool that is being used now days to correlate the genetic similarity or mutations between species. The simplicity and wide applicability of RAPD analysis mainly depend upon the use of short nucleotide primers, which were unrelated to known DNA sequences of the target organism [33]. DNA polymorphisms can be efficiently detected using the PCR primers and identify inter-strain variations among species in treated samples [34]. The degree of relatedness and genetic mapping can be correlated between similar or different treated sample species [35].

The DNA fingerprinting by RAPD analysis using five primers was carried out on the control and treated samples. DNA fingerprinting by RAPD analysis of the control and treated samples are shown in Figure 1, and the polymorphic bands are marked by arrows. The RAPD patterns of treated samples showed some unique and dissimilar patterns. DNA polymorphism analyzed by the RAPD analysis was presented in Table 3 . The level of polymorphism between control and treated samples (A, A1, B, and B1) are summarized in Table 4 . The level of polymorphism was found in an average range of 34 to $53 \%$ in treated samples as compared to control in $N$. otitidis after the biofield treatment. The highest change in DNA sequence was observed in treated groups with RBA 13A primer as compared to the control; a negligible change was found in treated group with RBA 8A primer as compared to the control (Table 3 and 4).

\section{S rDNA genotyping}

The bacteria that are poorly differentiated by conventional methods needs molecular analysis method like $16 \mathrm{~S}$ rDNA sequence [36]. This molecular-based technique is a suitable tool for identification of most
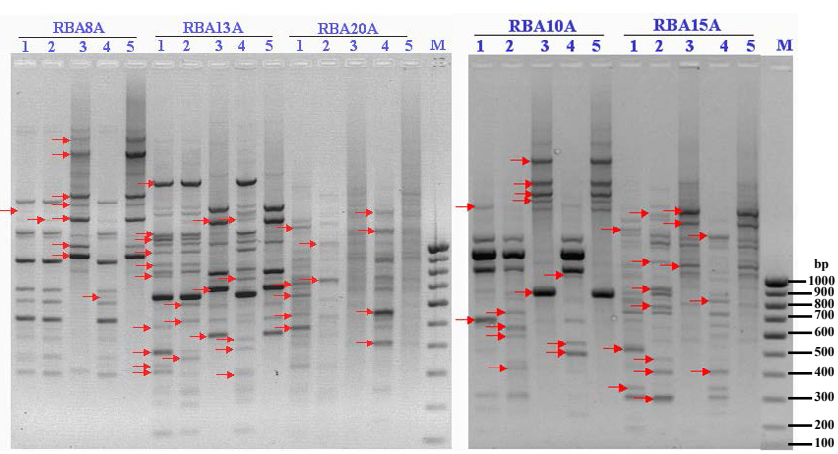

Figure 1: Random amplified polymorphic-DNA fragment patterns of Nocardia otitidis generated using five RAPD primers, RBA 8A, RBA 13A, RBA 20A, RBA 10A and RBA 15A. 1: Control; 2: Treated A; 3: Treated A-1; 4: Treated B; 5 : Treated B-1; M: 100 bp DNA Ladder. 


\begin{tabular}{|c|c|c|c|c|c|c|c|c|c|}
\hline \multirow{2}{*}{ S. No. } & \multirow{2}{*}{ Primer } & \multirow{2}{*}{$\begin{array}{l}\text { Nucleotide Sequence } \\
\qquad\left(5^{\prime}-3^{\prime}\right)\end{array}$} & \multirow{2}{*}{ Band Scored } & \multirow{2}{*}{$\begin{array}{l}\text { Common Bands in } \\
\text { Control and Treated }\end{array}$} & \multicolumn{5}{|c|}{ Unique Band } \\
\hline & & & & & Control & TSA & TSA-1 & TSB & TSB-1 \\
\hline 1. & RBA 8A & GTTTCGCTCC & 19 & - & 1 & 1 & 5 & 1 & - \\
\hline 2. & RBA 13A & GTGGATCCGA & 21 & 2 & 3 & 2 & - & 4 & - \\
\hline 3. & RBA 20A & GCGATCCCCA & 15 & 2 & 3 & 1 & - & 4 & - \\
\hline 4. & RBA 10A & CCGCAGCCAA & 19 & - & 2 & 3 & 1 & 3 & - \\
\hline 5. & RBA 15A & AAGAGCCCGT & 25 & 2 & 2 & 3 & - & 1 & - \\
\hline
\end{tabular}

TSA: Treated sample A; TSA-1: Treated sample A-1; TSB: Treated sample B; TSB-1: Treated sample B-1; -, No band

Table 3: DNA polymorphism analyzed by random amplified polymorphic DNA (RAPD) analysis.

\begin{tabular}{|c|c|c|c|c|c|c|c|c|}
\hline Primer & $\mathrm{C}$ and TSA & $\mathrm{C}$ and TSA-1 & $\mathrm{C}$ and TSB & $\mathrm{C}$ and TSB-1 & TSA and TSA-1 & TSB and TSB-1 & TSA and TSB & TSA-1 and TSB-1 \\
\hline \multicolumn{9}{|c|}{$\%$} \\
\hline RBA 8A & 15 & 53 & 15 & 7 & 53 & 7 & 0 & 46 \\
\hline RBA 13A & 53 & 60 & 100 & 60 & 71 & 68 & 47 & 0 \\
\hline RBA 20A & 50 & 35 & 57 & 35 & 22 & 33 & 7 & 0 \\
\hline RBA 10A & 54 & 90 & 36 & 54 & 91 & 100 & 18 & 36 \\
\hline RBA 15A & 56 & 31 & 25 & 18 & 52 & 62 & 31 & 13 \\
\hline Average polymorphism & 45 & 53 & 46 & 34 & 57 & 54 & 20 & 19 \\
\hline
\end{tabular}

C: Control; TSA: Treated Sample A; TSA-1: Treated Sample A-1; TSB: Treated Sample B; TSB-1: Treated Sample B-1

Table 4: Level of polymorphism between control and treated samples.

\begin{tabular}{|c|c|c|c|}
\hline Alignment View & AN & Alignment Results & Sequence Description \\
\hline 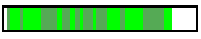 & $9 \mathrm{~A} 1$ & 0.99 & Sample studied \\
\hline 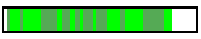 & $9 \mathrm{~A}$ & 0.89 & Enterobacter aerogenes \\
\hline 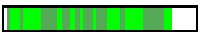 & AB244467 & 0.99 & Enterobacter aerogenes strain: C1111 \\
\hline 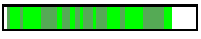 & AB244456 & 0.98 & Enterobacter aerogenes strain: An19-2 \\
\hline+2 & AJ251468 & 0.98 & Enterobacter aerogenes strain NCTC10006T \\
\hline 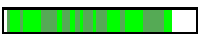 & AM184245 & 0.97 & Kluyvera cryocrescens strain WAB1904 \\
\hline - & AJ251467 & 0.98 & Klebsiella ornithinolytica strain JCM6096T \\
\hline+0 & X93216 & 0.98 & Klebsiella planticola strain DR3 \\
\hline$\square$ & AB364958 & 0.98 & Raoultella ornithinolytica \\
\hline $\mathrm{n}$ & AB353045 & 0.98 & Klebsiella oxytoca strain: No.5 \\
\hline$\square$ & AB094655 & 0.98 & Nocardia beijingensis strain: IFM 10052 \\
\hline$\square$ & AB094654 & 0.98 & Nocardia beijingensis strain: IFM 0915 \\
\hline
\end{tabular}

AN: GenBank Accession Number

Table 5: The closest sequences of Nocardia otitidis from sequence alignment using NCBI GenBank and ribosomal database project (RDP).

of the bacteria on their genus and/or species level by comparison with databases in the public domain. Because, most of the bacteria have possess small ribosomal subunit with species-specific variability [37]. The 16S rDNA sequence was determined in treated samples of $N$. otitidis and coded as 9A and 9A1 (sub cultured sample), which are shown in Table 5. The alignment and comparison of the consensus gene sequences were performed with the sequences stored in GenBank database available from NCBI using the algorithm BLASTn program.

Based on nucleotide homology and phylogenetic analysis of the microbe, the samples $9 \mathrm{~A}$ and $9 \mathrm{~A} 1$ (N. otitidis) were detected as Enterobacter aerogenes (GenBank Accession Number: AJ251468) with $98 \%$ identity of gene sequencing data. The nearest homolog genusspecies of N. otitidis (9A and 9A1) was found as Kluyvera cryocrescens (Accession No. AM184245). Some other close homologs of N. otitidis were found from the alignment results as shown in Table 5. The distance matrix based on nucleotide sequence homology data are presented in Table 6 . The phylogenetic tree was established using BLAST-Webpage
(NCBI). According to Table 6, ten different related bacterial species of N. otitidis were selected as Operational Taxonomic Units (OTUs) in order to investigate the phylogenetic relationship of $N$. otitidis. There were 1462 base-pair nucleotides of 16S rDNA gene sequences, which were analyzed and multiple alignments were constructed using ClustalW in MEGA3.1 [31]. The numbers of base substitutions per site from pairwise distance analysis between sequences are shown in Table 6. All the results were based on the pairwise analysis of 11 sequences. According to the data presented in Table 6, the lowest value of the genetic distance from $N$. otitidis was 0.018 base substitutions per site. This value is due to the distance between Enterobacter aerogenes and Kluyvera cryocrescens. All pairwise distance analysis was carried out using the p-distance method in MEGA3.1. The proportion of remarked distance, sometimes also called p-distance and showed as the number of nucleotide distances site. Values in Table 6 are programmed into Figure 2 with optimal bootstrap consensus tree. In the phylogram, there were eleven OTUs. The results suggested that after biofield treatment 
Citation: Trivedi MK, Branton A, Trivedi D, Nayak G, Mondal SC, et al. (2015) Evaluation of Antibiogram, Genotype and Phylogenetic Analysis of Biofield Treated Nocardia otitidis. Biol Syst Open Access 4: 143. doi:10.4172/2329-6577.1000143

Page 5 of 6

\begin{tabular}{|c|c|c|c|c|c|c|c|c|c|c|c|c|c|}
\hline \multicolumn{14}{|c|}{ Distance Matrix } \\
\hline AN & & 1 & 2 & 3 & 4 & 5 & 6 & 7 & 8 & 9 & 10 & 11 & 12 \\
\hline AB244456 & 1 & - & 0.992 & 1 & 0.990 & 1 & 0.992 & 0.982 & 0.988 & 0.720 & 0.720 & 0.993 & 1 \\
\hline AJ251467 & 2 & 0.008 & - & 0.992 & 0.998 & 0.992 & 1 & 0.973 & 0.991 & 0.720 & 0.720 & 0.991 & 0.992 \\
\hline AB244467 & 3 & 0.000 & 0.008 & - & 0.990 & 1 & 0.992 & 0.982 & 0.988 & 0.720 & 0.720 & 0.993 & 1 \\
\hline X93216 & 4 & 0.010 & 0.002 & 0.010 & - & 0.990 & 0.998 & 0.971 & 0.988 & 0.719 & 0.719 & 0.988 & 0.990 \\
\hline AJ251468 & 5 & 0.000 & 0.008 & 0.000 & 0.010 & - & 0.992 & 0.982 & 0.988 & 0.720 & 0.720 & 0.993 & 1 \\
\hline AB364958 & 6 & 0.008 & 0.000 & 0.008 & 0.002 & 0.008 & - & 0.973 & 0.991 & 0.720 & 0.720 & 0.991 & 0.992 \\
\hline $9 A$ & 7 & 0.018 & 0.027 & 0.018 & 0.029 & 0.018 & 0.027 & - & 0.969 & 0.702 & 0.702 & 0.974 & 0.982 \\
\hline AB353045 & 8 & 0.012 & 0.009 & 0.012 & 0.012 & 0.012 & 0.009 & 0.031 & - & 0.721 & 0.721 & 0.989 & 0.988 \\
\hline AB094654 & 9 & 0.280 & 0.280 & 0.280 & 0.281 & 0.280 & 0.280 & 0.298 & 0.279 & - & 1 & 0.717 & 0.720 \\
\hline AB094655 & 10 & 0.280 & 0.280 & 0.280 & 0.281 & 0.280 & 0.280 & 0.298 & 0.279 & 0.000 & - & 0.717 & 0.720 \\
\hline AM184245 & 11 & 0.007 & 0.009 & 0.007 & 0.012 & 0.007 & 0.009 & 0.026 & 0.011 & 0.283 & 0.283 & - & 0.993 \\
\hline 9A1 & 12 & 0.000 & 0.008 & 0.000 & 0.010 & 0.000 & 0.008 & 0.018 & 0.012 & 0.280 & 0.280 & 0.007 & - \\
\hline
\end{tabular}

AN: GenBank Accession Number

Table 6: Distance matrix Nocardia otitidis samples (9A and 9A1) based on nucleotide sequence homology (Using Kimura-2 Parameter) indicates nucleotide similarity

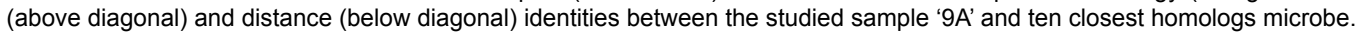

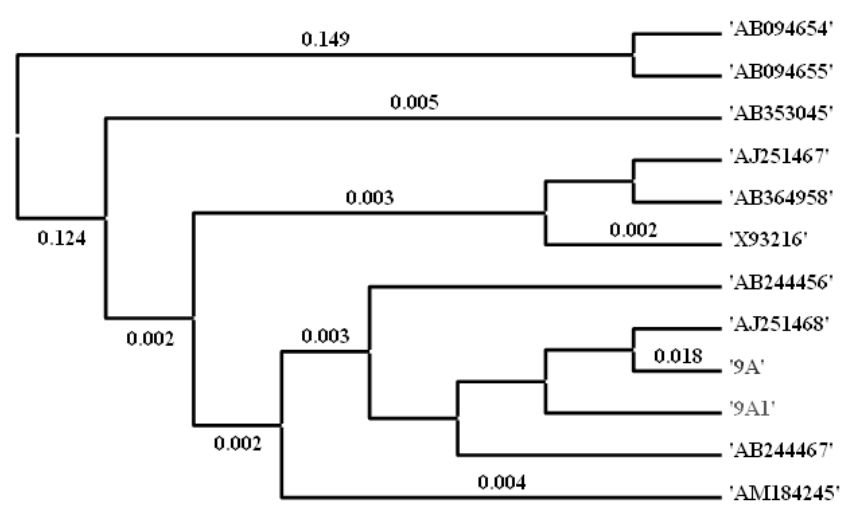

Figure 2: Phylogenetic tree of the partial 16S rDNA gene sequencing of Nocardia otitidis using MEGA 3.1 software using neighbor joining method (Numbers represent GenBank accession number).

followed by $16 \mathrm{~S}$ gene sequencing, the coded sample (9A) was detected as Enterobacter aerogenes which was closely related to the Kluyvera cryocrescens with $98 \%$ similarity and the lowest genetic distance were 0.018 base substitutions per site. Based on above findings, authors assumed the sustainability of The Trivedi Effect ${ }^{\circ}$ in subcultured sample (9A1), as similar type of data was observed in the case of sub-cultured sample of $N$. otitidis.

Due to microbial resistance to a single drug or multiple drugs, the invention of an effective antimicrobial therapy for the human-wellness is urgently required. However, due to some limitations of science, the progress of new medications is slow and very challenging for scientists. Biofield treatment might be responsible for doing alteration in microorganism at the genetic level and/or enzymatic level, which may act on the receptor protein. While altering the receptor protein, ligand-receptor/protein interactions may altered that could lead to show different phenotypic characteristics [38]. Based on these results, it is expected that biofield treatment has the scope to be a cost effective and alternative approach than the existing antimicrobial therapy in near future (Table 5 and 6).

\section{Conclusions}

Altogether, the biofield treatment has altered the MIC values
(16.67\%) of tested antimicrobials against the strain of N. otitidis. Using RAPD markers, the sample was characterized and showed interspecific relationships with $N$. otitidis after biofield treatment. The molecular method using $16 \mathrm{~S}$ rDNA analysis showed that samples were detected as Enterobacter aerogenes (GenBank Accession Number: AJ251468) with 98\% identity of gene sequencing data that was nearest homolog species to Kluyvera cryocrescens (Accession No. AM184245). The results suggest that there is an impact of biofield treatment on MIC, $16 \mathrm{~S}$ rDNA analysis, and DNA polymorphism of $N$. otitidis. These changes were found in the organism may be due to alterations happened at the genetic level after biofield treatment. Overall, it seems that Mr. Trivedi’s unique biofield energy treatment might be used as an alternate treatment approach in future antimicrobial therapy.

\section{Acknowledgement}

Authors gratefully acknowledged to Trivedi science, Trivedi testimonials and Trivedi master wellness and the whole team of PD Hinduja National Hospital and MRC, Mumbai, Microbiology Lab for their support. Authors also would like to thanks Bangalore Genei Pvt. Ltd., for conducting 16S rDNA sequencing and RAPD analysis.

\section{References}

1. Saubolle MA, Sussland D (2003) Nocardiosis: Review of clinical and laboratory experience. J Clin Microbiol 41: 4497-4501.

2. Wilson JW (2012) Nocardiosis: Updates and clinical overview. Mayo Clin Proc 87: 403-407.

3. Brown-Elliott BA, Brown JM, Conville PS, Wallace RJ Jr (2006) Clinical and laboratory features of the Nocardia spp. based on current molecular taxonomy. Clin Microbiol Rev 19: 259-282.

4. Mordarska H, Mordarski M, Goodfellow M (1972) Chemotaxonomic characters and classification of some nocardioform bacteria. J Gen Microbiol 71: 77-86.

5. Angeles AM, Sugar AM (1987) Rapid diagnosis of nocardiosis with an enzyme immunoassay. J Infect Dis 155: 292-296.

6. Saubolle AM (2002) Aerobic actinomycetes. Diagnostic microbiology of the immunocompromised host, ASM Press, Washington, DC.

7. Long PF (1994) A retrospective study of Nocardia infections associated with the acquired immune deficiency syndrome (AIDS) Infection 22: 362-364.

8. Filice GA (2005) Nocardiosis in persons with human immunodeficiency virus infection, transplant recipients, and large, geographically defined populations. J Lab Clin Med 145: 156-162.

9. Climenhaga DB, Tokarewicz AC, Willis NR (1984) Nocardia keratitis. Can J Ophthalmol 19: 284-286.

10. Beaman BL, Burnside J, Edwards B, Causey W (1976) Nocardial infections in the United States, 1972-1974. J Infect Dis 134: 286-289. 
Citation: Trivedi MK, Branton A, Trivedi D, Nayak G, Mondal SC, et al. (2015) Evaluation of Antibiogram, Genotype and Phylogenetic Analysis of Biofield Treated Nocardia otitidis. Biol Syst Open Access 4: 143. doi:10.4172/2329-6577.1000143

11. Benbow EP Jr., Smith DT, Grimson KS (1944) Sulfonamide therapy in actinomycosis: Two cases caused by aerobic partially acid-fast Actinomyces. Am Rev Tuberc 49: 395-407.

12. Wallace RJ Jr, Septimus EJ, Williams TW Jr, Conklin RH, Satterwhite TK, et al. (1982) Use of trimethoprim-sulfamethoxazole for treatment of infections due to Nocardia. Rev Infect Dis 4: 315-325.

13. Koithan M (2009) Introducing Complementary and Alternative Therapies. J Nurse Pract 5: 18-20

14. Burr HS (1957) Bibliography of Harold Saxton Burr. Yale J Biol Med 30: 163 167.

15. Hammerschlag R, Jain S, Baldwin AL, Gronowicz G, Lutgendorf SK, et al. (2012) Biofield research: A roundtable discussion of scientific and methodological issues. J Altern Complement Med 18: 1081-1086.

16. Movaffaghi Z, Farsi M (2009) Biofield therapies: Biophysical basis and biological regulations? Complement Ther Clin Pract 15: 35-37.

17. Niggli HJ, Tudisco S, Privitera G, Applegate LA, Scordino A, et al. (2005) Laserultraviolet-A-induced ultraweak photon emission in mammalian cells. J Biomed Opt 10: 024006

18. Sun Y, Wang C, Dai J (2010) Biophotons as neural communication signals demonstrated by in situ biophoton autography. Photochem Photobiol Sci 9 : 315-322.

19. Prakash S, Chowdhury AR, Gupta A (2015) Monitoring the human health by measuring the biofield "aura": An overview. IJAER 10: 27637-27641.

20. Sances F, Flora E, Patil S, Spence A, Shinde V (2013) Impact of biofield treatment on ginseng and organic blueberry yield. Agrivita J Agric Sci 35: 22-29.

21. Lenssen AW (2013) Biofield and fungicide seed treatment influences on soybean productivity, seed quality and weed community. Agricultural Journal 83: $138-143$

22. Trivedi MK, Patil S, Shettigar H, Bairwa K, Jana S (2015) Phenotypic and biotypic characterization of Klebsiella oxytoca: An impact of biofield treatment. J Microb Biochem Technol 7: 203-206.

23. Trivedi MK, Patil S, Shettigar H, Gangwar M, Jana S (2015) An effect of biofield treatment on multidrug-resistant Burkholderia cepacia: A multihost pathogen. J Trop Dis 3: 167

24. Trivedi MK, Patil S, Shettigar H, Gangwar M, Jana S (2015) Antimicrobia sensitivity pattern of $P$ seudomonas fluorescens after biofield treatment. J Infect Dis Ther 3: 222.
25. Dabhade VV, Tallapragada RR, Trivedi MK (2009) Effect of external energy on atomic, crystalline and powder characteristics of antimony and bismuth powders. Bull Mater Sci 32: 471-479.

26. Trivedi MK, Nayak G, Patil S, Tallapragada RM, Latiyal O (2015) Studies of the atomic and crystalline characteristics of ceramic oxide nano powders after bio field treatment. Ind Eng Manage 4: 161.

27. Patil SA, Nayak GB, Barve SS, Tembe RP, Khan RR (2012) Impact of biofield treatment on growth and anatomical characteristics of Pogostemon cablin (Benth.). Biotechnology 11: 154-162.

28. Nayak G, Altekar N (2015) Effect of biofield treatment on plant growth and adaptation. J Environ Health Sci 1: 1-9.

29. Woods GL, Brown-Elliott BA, Desmond EP, Hall GS, Heifets L, et al. (2003) Susceptibility testing of Mycobacteria, Nocardiae, and other aerobic Actinomycetes; Approved Standard. NCCLS document M24-A, 2003.

30. Welsh J, McClelland M (1990) Fingerprinting genomes using PCR with arbitrary primers. Nucleic Acids Res 18: 7213-7218.

31. Kumar S, Tamura K, Nei M (2004) MEGA3: Integrated software for Molecula Evolutionary Genetics Analysis and sequence alignment. Brief Bioinform 5: 150-163.

32. Burgert S (1998) Nocardiosis: A clinical review. Infect Dis Clin Pract 8: 27-32.

33. Williams JG, Kubelik AR, Livak KJ, Rafalski JA, Tingey SV (1990) DNA polymorphisms amplified by arbitrary primers are useful as genetic markers. Nucleic Acids Res 18: 6531-6535.

34. Bingen E, Boissinot C, Desjardins P, Cave H, Brahimi N, et al. (1993) Arbitrarily primed polymerase chain reaction provides rapid differentiation of Proteus mirabilis isolates from a pediatric hospital. J Clin Microbiol 31: 1055-1059.

35. Williams JG, Hanafey MK, Rafalski JA, Tingey SV (1993) Genetic analysis using random amplified polymorphic DNA markers. Methods Enzymol 218: 704-740.

36. Drancourt M, Bollet C, Carlioz A, Martelin R, Gayral JP, et al. (2000) 16S ribosomal DNA sequence analysis of a large collection of environmental and clinical unidentifiable bacterial isolates. J Clin Microbiol 38: 3623-3630.

37. Vandamme P, Pot B, Gillis M, de Vos P, Kersters K, et al. (1996) Polyphasic taxonomy, a consensus approach to bacterial systematics. Microbiol Rev 60 407-438.

38. Lindstrom E, Mild KH, Lundgren E (1998) Analysis of the T cell activation signaling pathway during ELF magnetic field exposure, p56 $6^{\text {lck }}$ and $\left[\mathrm{Ca}^{2+}\right.$ --measurements. Bioeletrochem Bioenerg 46: 129-137. 